\title{
PEMAHAMAN KONSEP MAHASISWA PEREMPUAN DALAM MENYELESAIKAN MASALAH GRUP
}

\author{
Suesthi Rahayuningsih \\ Universitas Islam Majapahit, Mojokerto \\ esthiachmad@gmail.com
}

\begin{abstract}
ABSTRAK
Penelitian ini bertujuan mendeskripsikan pemahaman konsep mahasiswa perempuan dalam menyelesaikan masalah grup. Penelitian ini dilakukan pada mahasiswa Universitas Islam Majapahit, Mojokerto. Subjek yang digunakan dalam penelitian ini diambil dari mahasiswa Program Studi pendidikan matematika, yaitu mahasiswa perempuan. Penelitian ini merupakan penelitian deskripsi kualitatif. Pengumpulan data dilakukan dengan wawancara berbasis tugas. Wawancara tersebut mengungkap pemahaman konsep berdasarkan indikator: Menjelaskan atau menyatakan ulang konsep dan menggunakan konsep grup dalam menyelesaikan masalah grup. Data dalam penelitian ini berupa hasil wawancara dan tes masalah matematika.Hasil penelitian menunjukkan bahwa Pemahaman konsep subjek, pada komponen menjelaskan atau menyatakan ulang konsep oparasi biner, sifat elemen identitas, sifat setiap elemen dan grup memiliki invers terjadi miskonsepsi, subjek kurang tepat dalam menyatakannya. Pada konsep sifat tertutup dan sifat assosiatif, subjek dapat menjelaskan dengan tepat. Pada komponen memberi contoh dan bukan contoh. subjek belum mampu membedakan mana merupakan operasi biner dan mana bukan demikian juga himpunan yang mempunyai elemen identitas dan himpunan yang setiap elemennya mempunyai invers. Subjek mampu membedakan mana yang merupakan operasi biner yang bersifat assosiatif dan mana yang tidak bersifat assosiatif.. Demikian juga dalam memberi contoh grup, tetapi hanya dengan operasi biner penjumlahan dan perkalian serta bukan contoh. Pada komponen menggunakan konsep grup dalam menyelesaikan masalah grup. Subjek menunjukkan G diberikan operasi perkalian adalah grup, dengan menunjukkan sifat tertutup, sifat assosiatif, memiliki elemen identitas dan memiliki invers setiap elemen.
\end{abstract}

Kata kunci: mahasiswa perempuan, masalah grup, pemahaman konsep

\section{ABSTRACT}

This study aims to describe the concept of female students in solving group problems. This research was conducted on students of Islamic University of Majapahit, Mojokerto. Subjects used in this study were taken from students of Mathematics education program, ie female students. This research is a qualitative description research. Data collection is done by task-based interviews. The interview reveals an understanding of concepts based on indicators: Explain or reiterate concepts and use group concepts to solve group problems. The data in this research is the result of interview and test of mathematics problem. The result of research indicates that understanding of subject concept, on component explaining or reiterating the concept of binary oparation, the nature of identity element, the nature of each element and group have inverse misconception, the subject is less precise in expressing it. In the concept of closed nature and associative nature, the subject can explain precisely. In the example component and not the example. the subject has not been able to distinguish which is a binary operation and which is not so also the set that has elements of identity and the set of which each element has an inverse. Subjects are able to distinguish which are binary operations that are assosiative and which are not associative. Similarly in giving a group example, but only by binary operation of addition and multiplication rather than example. The component uses group concepts to solve group problems. The subject shows $\mathrm{G}$ given the multiplication operation is the group, by showing the closed nature, the associative nature, having the identity element and having the inverse of each element.

Keyword: understanding of concepts; group problem; female students 


\section{Suesthi Rahayuningsih}

\section{PENDAHULUAN}

Matematika erat kaitannya dengan operasi dan konsep. Dalam pembelajaran matematika mahasiswa diharapkan dapat memahami dan menguasai konsep-konsep matematika. Kata menguasai di sini mengisyaratkan bahwa mahasiswa tidak sekedar tahu dan hafal tentang konsep-konsep matematika, melainkan mahasiswa harus mengerti dan memahami konsep-konsep tersebut dan menghubungkan keterkaitan suatu konsep dengan konsep yang lain (Listiawati, 2015).

Konsep adalah ide abstrak yang memungkinkan kita untuk mengelompokkan benda-benda (objek) ke dalam contoh dan non contoh (Ruseffendi, 2006). Konsep dasar dapat dipelajari melalui definisi atau penggunaan langsung. Disamping itu konsep juga dapat dipelajari dengan cara melihat, mendengar, mendiskusikan, dan memikirkannya. Menurut Sudjana(1989), Konsep atau pengertian adalah serangkaian perangsang dengan segala sifat-sifat yang sama. Sedangkan menurut Hamalik (2000) konsep adalah kelas/kategori stimulus yang memiliki ciri-ciri umum. Konsep matematika disusun secara berurutan sehingga konsep sebelumnya akan digunakan untuk mempelajari konsep selanjutnya. Misalkan konsep grup diajarkan terlebih dahulu dari pada konsep grup abelian. Pemahaman terhadap konsep materi prasyarat sangat penting karena mahasiswa menguasai konsep materi prasyarat maka mahasiswa lebih mudah untuk memahami konsep materi selanjutnya.

Pemahaman konsep adalah suatu kemampuan menemukan ide abstrak dalam matematika untuk mengklasifikasikan objek-objek yang biasanya dinyatakan dalam suatu istilah kemudian dituangkan kedalam contoh dan bukan contoh, sehingga seseorang dapat memahami suatu konsep (Gusniwati, 2015). Listiawati (2015) menyebutkan bahwa komponen pemahaman konsep grup antara lain menjelaskan atau menyatakan ulang konsep, memberi contoh dan bukan contoh serta menggunakan konsep grup dalam menyelesaikan soal. Sedangkan Darminto (2009) menyebutkan bahwa pemahaman konsep merupakan kompetensi yang dimiliki mahasiswa dengan beberapa indikator berikut: (1) menyatakan atau menjelaskan ulang sebuah konsep, (2) mengklasifikasikan sifat-sifat tertentu, (3) 
memberi contoh, (4) merepresentasikan konsep, (5) menggunakan konsep untuk menyelesaikan masalah.

Menyelesaikan masalah adalah suatu tindakan untuk menyelesaikan sebuah masalah atau proses yang menggunakan kekuatan atau manfaat matematika dalam menyelesaikan masalah, bisa juga dikatakan bahwa menyelesaikan masalah sebagai usaha mencari jalan keluar dari suatu kesulitan (Abdurrahman, 2003).Suatu masalah matematika yang sama misalnya diberikan pada beberapa individu, maka akan mendapatkan respon/tanggapan yang berbeda dalam menyelesaikannya. Perbedaan cara menyelesaikan tersebut karena setiap individu memiliki keunikan dalam dirinya. Hal lain yang mungkin dapat memunculkan perbedaan setiap individu dalam merespon suatu masalah adalah adanya perbedaan laki-laki dan perempuan. Mubeen, Saeed, \& Arif (2013) menjelaskan bahwa anak laki-laki berbeda dalam pencapaian prestasi matematika dari anak perempuan. Anak perempuan mencapai hasil yang lebih baik dibandingkan dengan anak laki-laki.

Mahasiswa Program Studi Pendidikan Matematika, Fakultas Pendidikan dan Ilmu Pendidikan, Universitas Islam Majapahit sebagai besar mahasiswa perempuan. Dan pemahaman mahasiswa terkait dengan konsep grup masih kurang, terlihat dari pengamatan penulis selama mengajar mata kuliah teori grup yang membahas masalah grup dan hasil belajar mahasiswa yang sebagian besar nilai mahasiswa masih dibawah 50. Hal ini sejalan dengan Findell (2001), beberapa penelitian telah menunjukkan bahwa pemahaman mahasiswa tentang konsep-konsep dalam aljabar abstrak kurang memuaskan. Padahal aljabar abstrak, pada kurikulum Prodi Pendidikan Matematika, Uiversitas Islam Majapahit, Mojokerto adalah Teori Grup merupakan mata kuliah wajib untuk mahasiswa program studi pendidikan matematika, Universitas Islam Majapahit. Sebagai mata kuliah wajib, tentunya mahasiswa diharapkan dapat menguasai konsep-konsep grup dan dapat menyelesaikan masalah grup yang diberikan. Sehingga Penulis tertarik untuk melakukan penelitian analisis pemahaman konsep mahasiswa perempuan dalam menyelesaikan masalah grup. Dan tujuan penelitian ini adalah mendeskripsikan pemahaman konsep mahasiswa perempuan dalam menyelesaikan masalah grup. 
Adapun indikator pemahaman konsep grup dalam penelitian ini mengadaptasi pada indikator dari Listiawati (2015) sebagai berikut:

Tabel 1. Indikator Pemahaman Konsep Grup

\begin{tabular}{|c|c|c|}
\hline No & Komponen Pemahaman Konsep Grup & Indikator \\
\hline 1. & $\begin{array}{l}\text { Menjelaskan atau menyatakan ulang } \\
\text { konsep }\end{array}$ & $\begin{array}{ll}\text { - } & \text { Menjelaskan pengertian operasi biner } \\
\text { - } & \text { Menjelaskan sifat tertutup } \\
\text { - } & \text { Menjelaskan sifat assosiatif } \\
\text { - } & \text { Menjelaskan sifat elemen identitas } \\
\text { - } & \text { Menjelaskan sifat setiap elemen } \\
& \text { memiliki invers } \\
\text { - } & \text { Menjelaskan definisi grup }\end{array}$ \\
\hline 2. & $\begin{array}{l}\text { Memberi contoh dan bukan } \\
\text { Contoh }\end{array}$ & $\begin{array}{l}\text { - } \begin{array}{l}\text { Memberikan contoh operasi biner } \\
\text { danbukan operasi biner }\end{array} \\
\text { - Memberi contoh operasi biner } \\
\text { yangbersifat assosiatif dan contoh yang } \\
\text { tidakbersifat assosiatif } \\
\text { - Memberi contoh himpunan } \\
\text { yangmempunyai elemen identitas dan } \\
\text { contohhimpunan yang tidak } \\
\text { mempunyaielemen identitas } \\
\text { - Memberi contoh himpunan yang } \\
\text { setiapelemennya mempunyai invers dan } \\
\text { contoh himpunan yang ada } \\
\text { elemennyatidak mempunyai invers } \\
\text { Memberi contoh grup dan bukan grup }\end{array}$ \\
\hline 3. & $\begin{array}{l}\text { Menggunakan konsep grup dalam } \\
\text { menyelesaikan masalah grup }\end{array}$ & $\begin{array}{l}\text { - Menunjukkan suatu himpunan dengan } \\
\text { operasi biner merupakan grup, dengan } \\
\text { menunjukkan } \quad \text { sifat tertutup, } \\
\text { menunjukkan sifat assosiatif, } \\
\text { menunjukkan mempunyai elemen } \\
\text { identitas dan menunjukkan mempunyai } \\
\text { invers setiap elemen }\end{array}$ \\
\hline
\end{tabular}

\section{METODE PENELITIAN}

Penelitian ini menggunakan metode penelitian deskriptif kualitatif. Metode deskriptif adalah suatu metode dalam meneliti status kelompok manuasia, obyek, suatu kondisi, suatu sistem pemikiran ataupun suatu kelas peristiwa pada masa sekarang. Tujuan dari penelitian deskriptif adalah untuk membuat deskripsi, gambaran atau lukisan secara sistematis, faktual dan akurat mengenai fakta-fakta, sifat-sifat serta hubungan antar fenomena yang diselidiki. Sedangkan menurut Moleong (2010) mendefinisikan metode kualitatif adalah prosedur penelitian yang 
menghasilkan data deskriptif berupa kata-kata tertulis atau lisan dari orang-orang dan perilaku yang dapat diamati. Dasar peneliti menggunakan pendekatan kualitatif adalah peneliti ingin mengetahui secara mendalam tentang pemahaman konsep mahasiswa perempuan calon guru dalam menyelesaikan masalah grup.

Subjek dalam penelitian ini adalah mahasiswa program studi pendidikan matematika, Universitas Islam Majapahit semester 6 yang telah menempuh mata kuliah Teori Grup. Pada penelitian ini hanya dipilih satu subjek yaitu mahasiswa perempuan yang komunikatif dan memiliki kemampuan matematika sedang. Instrumen dalam penelitian ini dikelompokkan menjadi instrumen utama dan instrument pendukung. Instrumen utama yaitu peneliti sendiri dan instrumen pendukung yaitu Soal Grup (SG) dan pedoman wawancara.Pengumpulan data dalam penelitian ini dilakukan dengan menggunakan metode wawancara berbasis tugas yang dilakukan oleh peneliti sendiri sebagai instrumen utama kepada subjek. Sebelum dilakukan wawancara, terlebih dahulu kepada subjek diberikan soal grup. Untuk memeriksa keabsahan data dalam penelitian ini, maka dilakukan triangulasi. Triangulasi yang digunakan dalam penelitian ini adalah triangulasi waktu.

Dan dalam penelitian ini analisis data dilakukan melalui (1) reduksi data,adapun proses reduksi data yang akan dilakukan, meliputi: mengumpulkan hasil pekerjaan subjek dari tes menyelesaikan masalah grup, memeriksa dan menelaah hasil tes. Kemudian membuat transkip data yang terdiri dari penjelasan mahasiswa terhadap penyelesaian masalah grup yang diberikan dalam bentuk tertulis, menelaah hasil rekaman wawancara. Kemudian membuat transkrip hasil wawancara dan memutar hasil rekaman berulang-ulang agar peneliti dapat menuliskan dengan tepat apa yang telah diungkapkan subjek dalam wawancara, memeriksa kembali hasil transkrip tersebut dengan mendengarkan kembali hasil wawancara dengan subjek terkait serta mereduksi data dengan membuat rangkuman inti wawancara, dengan cara membuang data yang tidak diperlukan, (2) Penyajian data serta (3) Penarikan kesimpulan. 


\section{Suesthi Rahayuningsih}

\section{HASIL PENELITIAN DAN PEMBAHASAN}

Dilakukan analisis data yang diperoleh dari wawancara berbasis tugas pada subjek untuk memperoleh pemahaman konsep mahasiswa dalam menyelesaikan masalah grup. Berdasarkan hasil analisis data, diperoleh sebagai berikut.

Pada komponen pertama, menjelaskan atau menyatakan ulang konsep. Pada konsep operasi biner, subjek mampu menyatakan ulang konsep oparasi biner dengan bahasa sendiri, tetapi terjadi miskonsepsi (salah konsep). Hal ini terlihat ketika subjek menjelaskan bahwa operasi biner itu adalah penjumlahan dan perkalian, dengan alasan pada soal operasi binernya adalah perkalian. Miskonsepsi merupakan pemaknaan konsep yang berbeda, bisa juga merupakan pengertian yang tidak akurat tentang konsep ( Wafiyah, 2012). Pada konsep sifat tertutup dan sifat assosiatif, subjek dapat menjelaskan dengan tepat sifat tertutup dan sifat assosiatif dengan bahasanya sendiri hal ini terlihat dari hasil wawancara peneliti. Pada konsep sifat elemen identitas,terjadi miskonsepsi kembali. Subjek kurang tepat dalam menyatakan ulang sifat elemen identitas. Hal ini nampak dari hasil wawancara yang dilakukan pada subjek, subjek menjelaskan bahwa elemen identitas adalah 1 atau 0, tidak memperhatikan himpunan dan operasi biner apa yang diberikan. Hal ini berkaitan dengan yang dinyatakan subjek dengan konsep operasi biner, yaitu operasi biner itu adalah perkalian dan penjumlahan. Jika operasi biner perkalian elemen identitasnya adalah 1 dan jika operasi binernya penjumlahan elemen identitasnya adalah 0.Hal ini sejalan dengan Amir(2015) konsep matematika sangat kompleks dan cukup sulit untuk dipahami apabila konsep yang lebih sederhana belum bisa dipahami siswa. Dan pada konsep sifat setiap elemen memiliki invers,menjelaskan invers elemen adalah kebalikan atau lawan dari suatu bilangan, dan suatu bilangan tersebut terdapat dalam himpunan yang diberikan operasi biner. Hali ini terjadi dikarenakan subjek pada konsep sifat setiap elemen memiliki invers masih bingung dalam menjelaskannya sehingga pada konsep ini subjek mengalami miskonsepsi. Dan berdasarkan Savitri (dalam Maulida, Mardiyana \& Pramudya, 2017) Hancock memandang miskonsepsi muncul dari penalaran yang salah, miskonsepsi juga diyakini berasal dari kebingungan atau kurangnya. Pada konsep Grup,subjek dapat menyatakan ulang 
konsep grup dengan bahasa sendiri, hal ini nampak dari hasil wawancara peneliti. Subjek menjelaskan grup adalah himpunan yang diberikan operasi biner yang memenuhi 4 sifat yaitu tertutup, assosiatif, memiliki elemen identitas dan memiliki invers, tidak menjelaskan bahwa himpunan yang diberikan operasi biner harus tidak kosong. Miskonsepsi tersebut dapat terjadi karena disebabkan oleh berbagai aspek, yaitu mahasiswa itu sendiri, guru/dosen, buku teks atau metode mengajar. Pada kasus ini, miskonsepsi terjadi karena adanya pemikiran dari subjek sendiri yang berbeda mengenai yang diterimanya. Menurut Barokah (dalam Maulida, Mardiyana \& Pramudya, 2017) Suparno menyatakan bahwa salah satu penyebab miskonsepsi yang berasal dari diri siswa adalah adanya berbagai jalan pikiran yang berbeda.

Pada komponen kedua, memberi contoh dan bukan contoh. subjek belum mampu membedakan mana merupakan operasi biner dan mana bukan, hal tersebut nampak dari hasil wawancara yang telah dilakukan peneliti, subjek menyebutkan operasi biner adalah penjumlahan dan perkalian selain itu bukan operasi biner. Dalam memberikan contoh dan bukan contoh operasi biner sesuai dengan pemahaman konsep subjek dalam menyatakan ulang konsep oparsi biner. Hal ini sejalan dengan Amir (2015) pengetahuan yang dimiliki seseorang (individu) sebelumnya dan tujuannya bagaimna ia menentukan apa yang relevan.Tetapi subjek mampu membedakan mana yang merupakan operasi biner yang bersifat assosiatif dan mana yang tidak bersifat assosiatif, hal ini terlihat dari hasil wawancara peneliti pada subjek ketika peneliti memberikan beberapa operasi biner. Dan juga dari hasil wawancara, Subjek hanya mampu memberi contoh himpunan yang mempunyai elemen identitas adalah 0 dan 1 dan tidak mampu memberi contoh himpunan yang tidak mempunyai elemen identitas. Hal ini juga berkaitan dengan contoh dan bukan contoh operasi biner yang diberikan subjek. Dalam memberi contoh himpunan yang setiap elemennya mempunyai invers dan contoh himpunan yang ada elemennya tidak mempunyai invers, subjek tidak mampu memberi contoh dan bukan contoh. Sedangkan dalam memberi contoh grup dan bukan grup, subjek mampu memberi contoh grup walaupun hanya dengan operasi biner penjumlahan dan perkalian serta bukan contoh.Dari paparan diatas, terlihat subjek kurang tepat dalam memberi contoh dan bukan contoh 
operasi biner, himpunan yang mempunyai elemen identitas, himpunan yang setiap elemennya mempunyai invers dan grup hal ini dikarenakan subjek belum memilki kemampuan dalam memahami konsep tersebut. Hal ini sejalan dengan Amir (2015) Seorang siswa memiliki kemampuan dalam memahami suatu konsep matematika apabila ia telah mampu melakukan beberapa hal, salah satunya adalah memberikan contoh (dan bukan contoh) atau ilustrasi yang berkaitan dengan suatu konsep guna memperjelas konsep tersebut.

Pada komponen ketiga, menggunakan konsep grup dalam menyelesaikan masalah grup. Subjek dalam menunjukkan bahwa himpunan $G$ dengan operasi biner perkalian merupakan grup, terlebih dahulu menunjukkan bahwa $G=\{-i, i$, 1, -1 \} diberikan operasi perkalian merupakan grup dengan menunjukkan sifat tertutup kemudian sifat assosiatif, memiliki elemen identitas serta memiliki invers setiap elemen $G$ tetapi tidak menjelaskan terlebih dahulu bahwa $G$ adalah himpunan tak kosong, hal ini terlihat dari jawabannya. Subjek dalam menunjukan sifat tertutup, tidak menunjukan bahwa setiap elemen dalam $\mathrm{G}$ diberikan operasi perkalian bersifat tertutup, hanya menunjukkan dengan mengambil 3 anggota $G$ yaitu -1 , $\mathrm{i}$ dan 1 , sehingga diperoleh $-1 \times 1=-1$ dan -1 x $\mathrm{i}=-\mathrm{i}$, kemudian disimpulkan bahwa bersifat tertutup. Dari hasil wawancara peneliti kepada subjek, subjek sebenarnya masih bingung dalam menujukkan sifat tertutup. Subjek menyampaikan seharusnya berlaku untuk setiap elemen $G$ tetapi tidak dapat menuliskan dalam jawabannya.Langkah kedua subjek menunjukan sifat assosiatif , subjek hanya ambil 3 anggota $\mathrm{G}$ yaitu -1, i dan 1, kemudian disimpulkan bahwa bersifat assosiatif. Subjek menganggap bahwa dengan ambil 3 anggota G sudah cukup menunjukkan bahwa $\mathrm{G}$ diberikan operasi perkalian bersifat tertutup dan bersifat assosiatif.Hal ini nampak dalam hasil wawancara yang dilakukan peneliti kepada subjek. Selanjutnya langkah ketiga subjek menunjukkan himpunan G dengan operasi perkalian memiliki elemen identitas, yang nampak dari jawabannya. Subjek memisalkan elemen identitasnya adalah e $=1$, dengan ambil $\mathrm{a} \in G$, berlaku a. $1=1$. $\mathrm{a}=\mathrm{a}$, untuk setiap a anggota $\mathrm{G}$. Subjek memisalkan 1 karena subjek menyampaikan elemen identitas itu adalah 1 atau 0 dan dalam soal ini subjek memisalkan 1 karena operasi biner yang diberikan perkalian. Hal ini nampak dalam hasil wawancara peneliti kepada subjek. Temuan ini sesuai dengan 
pemahaman subjek dalam menyatakan ulang konsep elemen identitas. Tetapi subjek hanya mengambil $1 \in \mathrm{G}, 1.1=1.1=1$, karena 1 merupakan elemen identitas. Kemudian menyimpulkan bahwa $\mathrm{G}$ dengan operasi perkalian memiliki elemen identitas yaitu 1. Hal ini terlihat dari jawabannya, subjek menganggap hal itu cukup dalam untuk menyimpulkan bahwa 1 merupakan elemen identitasnya.Langkah berikutnya subjek menunjukkan bahwa $G$ mempunyai invers untuk setiap a anggota $\mathrm{G}$ mempunyai invers dengan memisalkan a. $\mathrm{a}^{-1}=\mathrm{e}$, kemudian menjelaskan bahwa $1 .-1=-1$ dan $-1.1=-1$ serta i. $-\mathrm{i}=-1$ dan i. $-\mathrm{i}=-1$. Terlihat dari jawabannya, subjek tidak menggunakan elemen identitas ditemukan pada langkah sebelumnya, yaitu e $=1$. Subjek menjelaskan bahwa invers dari suatu elemen 1 adalah -1 dan $\mathrm{i}$ adalah $-\mathrm{i}$, dan -1 dan $-\mathrm{i}$ yang dianggap subjek sebagai kebalikan dari 1 dan i. Subjek menganggap bahwa invers dari elemen adalah kebalikannya, dari hasil wawancara peneliti kepada subjek. Setelah menunjukkan sifat tertutup, sifat assosiatif, memiliki elemen identitas dan invers setiap elemen $G$ secara berurutan sesuai dengan pemahaman subjek dalam menjelaskan atau menyatakan ulang konsep grup, subjek menyimpulkan bahwa $\mathrm{G}$ $=\{1,-1, i,-i\}$ diberikan operasi perkalian merupakan grup. Dari hasil wawancara peneliti kepada subjek, dikarenakan 4 syarat grup terpenuhi.Dari Paparan tersebut, Subjek dalam menunjukkan bahwa himpunan $G$ dengan operasi biner perkalian merupakan grup sesuai dengan pemahaman konsep subjek dalam menyatakan ulang konsep grup. Hal ini sesuai dengan pandangan O'Connell (2007) bahwa dengan pemahaman konsep, siswa akan lebih mudah dalam memecahkan permasalahan karena siswa akan mampu mengaitkan serta memecahkan permasalahan tersebut dengan berbekal konsep yang sudah dipahaminya. Dan temuan ini sesuai pendapat Hudojo (1990) menjelaskan dalam menyelesaikan masalah, peserta didik perlu memahami proses penyelesaian masalah dan terampil dalam memilih konsep yang relevan.

\section{SIMPULAN}

Pemahaman konsep subjekdalam menyelesaikan masalah grup, pada komponen menjelaskan atau menyatakan ulang konsep. Dalam menjelaskan konsep operasi biner, subjek mampu menyatakan ulang konsep oparasi biner 


\section{Suesthi Rahayuningsih}

dengan bahasa sendiri, tetapi terjadi miskonsepsi (salah konsep). Pada konsep sifat tertutup dan sifat assosiatif, subjek dapat menjelaskan dengan tepat. Pada konsep sifat elemen identitas, terjadi miskonsepsi kembali. Subjek kurang tepat dalam menyatakan ulang sifat elemen identitas. Pada konsep sifat setiap elemen memiliki invers, subjek menjelaskan invers elemen adalah kebalikan atau lawan dari suatu bilangan, dan suatu bilangan tersebut terdapat dalam himpunan yang diberikan operasi biner. Dan pada konsep grup, subjek dapat menyatakan ulang konsep grup dengan bahasa sendiri, subjek menjelaskan grup adalah himpunan yang diberikan operasi biner yang memenuhi 4 sifat yaitu tertutup, assosiatif, memiliki elemen identitas dan memiliki invers, tidak menjelaskan bahwa himpunan yang diberikan operasi biner harus tidak kosong.

Pada komponenmemberi contoh dan bukan contoh. subjek belum mampu membedakan mana merupakan operasi biner dan mana bukan, subjek menyebutkan operasi biner adalah penjumlahan dan perkalian selain itu bukan operasi biner. Tetapi subjek mampu membedakan mana yang merupakan operasi biner yang bersifat assosiatif dan mana yang tidak bersifat assosiatif. Dan subjek hanya mampu memberi contoh himpunan yang mempunyai elemen identitas adalah 0 dan 1 dan tidak mampu memberi contoh himpunan yang tidak mempunyai elemen identitas. Dalam memberi contoh himpunan yang setiap elemennya mempunyai invers dan contoh himpunan yang ada elemennya tidak mempunyai invers, subjek tidak mampu memberi contoh dan bukan contoh. Sedangkan dalam memberi contoh grup dan bukan grup, subjek mampu memberi contoh grup walaupun hanya dengan operasi biner penjumlahan dan perkalian serta bukan contoh.

Pada komponen menggunakan konsep grup dalam menyelesaikan masalah grup. Subjek dalam menyelesaikan masalah grup yang diberikan, menunjukkan $\mathrm{G}$ diberikan operasi perkalian adalah grup, dengan menunjukkan sifat tertutup, sifat assosiatif, memiliki elemen identitas dan memiliki invers setiap elemen secara berurutan sesuai pemahaman subjek dalam menjelaskan atau menyatakan ulang konsep grup. Tetapi dalam menunjukan sifat tertutup, sifat assosiatif, mengambil beberapa elemen $G$ saja, demikian juga dalam menunjukkan memiliki elemen identitas, ditunjukkan hanya berlaku untuk beberapa elemen G. Serta dalam 
menunjukkan invers setiap elemen, hanya mengambil beberapa elemen $G$ dan elemen identitas yang telah ditemukan tidak digunakan, dan menjelaskan bahwa invers elemen itu adalah kebalikannya. Dan subjek menyimpulkan himpunan G dengan operasi perkalian adalah grup.

\section{DAFTAR PUSTAKA}

Abdurahman, Mulyono. 2003. Pendidikan Bagi Anak Berkesulitan Belajar. Jakarta: PT Rineka Cipta.

Amir, A. 2015. Pemahaman Konsep dan Pemecahan Masalah dalam Pembelajaran Matematika. Logaritma: Jurnal Ilmu-ilmu Kependidikan dan Sains, Vol. 3, No. 01

Darminto, Bambang P. 2009. Upaya Peningkatan Pemahaman Konsep Aljabar dan Sikap Mahasiswa Calon Guru Matematika terhadap Pembelajaran Berbasis Komputer. Makalah dipresentasikan dalam Seminar Nasional Aljabar, Pengajaran dan Terapannya. Jurusan Pendidikan Matematika FMIPA UNY Yogyakarta.

Dewiyani. 2008. Mengajarkan Pemecahan Masalah Dengan Menggunakan Langkah Polya. Stikom Jurnal. Vol.12. No 2.

Farida, Nurul .2015. Analisis Kesalahan Siswa Smp Kelas VII Dalam Menyelesaikan Masalah Soal Cerita Matematika. Pendidikan Matematika Fkip Universitas Muhammadiyah Metro.

Gusniwati, Mira. 2015. Pengaruh Kecerdasan Emosional Dan Minat Belajar Terhadap Penguasaan Konsep Matematika Siswa Dalam Sman Di Kecamatan Kebon Jeruk. Jakarta.

Hudoyo, 2001. Common Textbook Pengembangan Kurikulum dan Pembelajaran Matematika. Malang: Jurdikmat Universitas Negeri Malang.

Kilpatrick, J., Swafford, J., \& Findell, B. (Eds.). 2001. Adding it Up: Helping Children Learn Mathematics. Washington, DC: National Academy Press.

Listiawati E, 2015. Mahasiswa Calon Guru Pada Konsep Grup. Jurnal APOTEMA, Vol. 1, No. 2, Juni 2015, 76-87.

Maulida, F,O, Mardiyana\&Pramudya, I.2017. Analisis Pemahaman Konsep Siswa Pada Materipersamaan Lingkaran Ditinjau Dari Motivasi Belajar Siswa Kelas Xii Ips 4 Sma Negeri 6 Surakarta Tahun Pelajaran 2016/2017.Jurnal Pendidikan Matematika dan Matematika (JPMM) Solusi Vol.I No.4.

Mubeen, S., Saeed, S., \& Arif, M.H. 2013. Attitiude towards mathematics and achademic achievement in mathematics among secondary level boys and girls. IOSR Journal of Humanities and Social Sciences, 6(4), 38-41.

Nana Sudjana. 1989. Dasar - Dasar Proses Belajar Mengajar. Bandung : Sinar Baru Algesindo.

Oemar Hamalik. 2000. Kurikulum dan Pembelajaran. Jakarta : Bumi Aksara.

Ruseffendi, E.T. 2006. Pengantar kepada Membantu Guru Mengembangkan Kompetensinya dalam Pengajaran Matematika untuk Meningkatkan CBSA. Bandung: Tarsito. 
Rofiqoh, Zeni. 2015. Analisis Kemampuan Pemecahan Masalah Matematika Siswa Kelas X dalam Pembelajaran Discovery Learning Berdasarkan Gaya Belajar Siswa. Skripsi Universitas Negeri Semarang.

Soedjadi, R. 2000. Kiat Pendidikan Matematika di Indonesia, Konstatasi Keadaan Masa Kini Menuju Harapan Masa Depan. Jakarta: Direktorat Jenderal Pendidikan Tinggi Departemen Pendidikan Nasional.

Van De Walle, John. A. 2008. Matematika Sekolah Dasar Dan Menengah. Jakarta : Erlangga.

Wafiyah, N. 2012. Identifikasi Miskonsepsi Siswa dan Faktor-faktor Penyebab pada Materi Permutasi dan Kombinasi di SMA Negeri 1 Manyar. Gamatika, Vol. II No. 2 